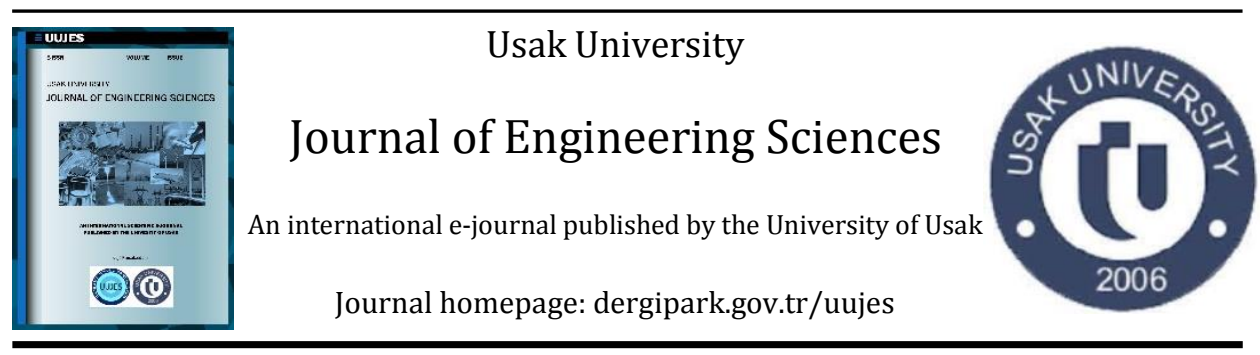

Research article

\title{
A CASE OF RISK ASSESSMENT BY USING FINE-KINNEY METHOD IN SUB-LEATHER PROCESSING
}

\author{
Ayhan Milli1* , Serdar Salman², Erhan Sancak ${ }^{3}$ \\ ${ }^{1}$ Department of Textile Clothing Footwear and Leather, Gerede Vocational School, Bolu Abant Izzet Baysal \\ University, Turkey \\ ${ }^{2}$ Department of Metallurgical and Materials Engineering, Faculty of Technology, Marmara University, Turkey \\ ${ }^{3}$ Department of Textile Engineering, Faculty of Technology, Marmara University, Turkey
}

\begin{abstract}
One of the most hazardous industries in the district of Bolu-Gerede of Turkey, leather-processing industry, takes an important place for the economy of the district and the country. The study was carried out in a medium-sized company operating in the leather processing sector in Bolu. Preventing the occurrence of industrial accidents and occupational diseases is one of points to be emphasized in terms of companies and laborers in the industry. Occupational health and safety are concepts that increasingly become more important in today's societies. Awareness is raised and legal issues come to the fore regarding these concepts comprising a dimension of human health. Scientists are studying on occupational health and safety and looking for ways to prevent the accidents before they occur. In the study, Fine-Kinney risk analysis method has been applied in the sub-processes of a sample manufacturing company in the district; and the activities whose risk scores are very high after the study and high-risk activities have been handled in the first place; and it is observed that the risk-scores decreased after the regulatory and preventive practices. As for other activities, whose risk scores are lower, action plans were implemented. With this study, it is stated that the risk assessment is a proactive approach in occupational health and safety practices and the company's risk scores have been significantly reduced.
\end{abstract}

Keywords: Occupational health and safety; Fine-Kinney method; risk analysis; leather; tannery.

(C)2021 Usak University all rights reserved.

\section{Introduction}

Chitin Leathercraft is the practice of making leather of animals like sheep, calf, pig and horse ready for industrial use by processing them with special methods. Turning the

\footnotetext{
*Corresponding author: Ayhan Milli

E-mail: ayhan.milli@ibu.edu.tr (ORCID: 0000-0002-5878-2354) 
leather into a product by processing them with different methods for various purposes is also defined as the main field of activity of the leather processing industry [1].

It is predicted that the leathercraft in Gerede dates back 700 years with the participation of this region to Ottoman territories and it corresponds to the early $13^{\text {th }}$ century, according to the communities living in this region. High altitude and cold \& rainy weather in Gerede district, pose an advantage for the leathercraft and it has evolved into a long-standing industry. It is thought that leather production, which has been made for many years in this district, constitutes an inherited skill over inhabitants of this district. It is expected that the factories built in newly built Leather Organized Industrial Zone will leave the traditional production methods and adopt new production methods (Lean Manufacturing, 6 Sigma, etc.).

On the other hand, as a result of the inventions of $18^{\text {th }}$ and $19^{\text {th }}$ centuries and accordingly after the mass production movements of the workplaces, new and unsafe working conditions were created for the employees. Laws on laborers and occupational health have been passed in order to turn the inappropriate working conditions arising from employees or workplaces into appropriate conditions. Social security principles, which started to come forward in Europe in $18^{\text {th }}$ century, became widespread in $19^{\text {th }}$ century, various insurance institutions were established. Then, insurances of occupational accidents and occupational diseases were introduced. The increase in business accidents, its technological complexity, development and implementation of industrial and international standards, a continuous trend of transition from emergency liquidation to prevention and risk management, have been a prerequisite for the development of risk management information system in the industrial field [2].

As of the 1980s, numerous studies have been conducted in terms of hazards and risks which may be encountered by leather industry employees. Leather production includes many operations with different exposures, which can be harmful to the health of the workers, and particularly be carcinogenic $[3,4]$. Some of these studies were conducted on cancer risk among leather factory employees [5], occupational physical risks of leather staff [6]. The Fine-Kinney occupational risk assessment method is a widely applied method to control risks in its application areas $[7,8]$.

In this study, a leather processing company operating in Gerede Leather Organized Industrial Zone was discussed and the risk assessment, being a preventive approach and required by law, was carried out. Fine Kinney risk assessment method was preferred because great numbers of chemicals were used in the industry. It is aimed to foresee the risks that the companies in leather industry may encounter on a sectoral basis (Leather industry), to ensure that pre-measures or measures are taken and to prevent occupational accidents before occurring, by a proactive approach in terms of occupational health and safety.

\section{The Concept of Occupational Health and Safety in Turkey and in the World}

According to International Labor Organization, an occupational accident is "an unexpected and unplanned occurrence", which results in an injury or damage. Occupational Health and Safety (OHS) is a concept which becomes increasingly important. Today, OHS is a fact not only considering employee and employer individually but also having economic, social and international dimensions [9]. Occupational Health is the efforts aiming to ensure that the employee can work tranquilly in a working environment where the threats arising from the work environment or the materials or equipment used, are eliminated or minimized [10]. 
At its first session in 1950, the Joint ILO (International Labor Organization) / WHO (World Health Organization) Committee on Occupational Health defined the purpose of occupational health. Then the definition was revised in 1995 as follows: Occupational health should aim: the promotion and maintenance of the highest degree of physical, mental and social well-being of workers in all occupations; the prevention of health problems caused by working conditions; the protection of workers in their employment from risks resulting from factors adverse to health; the placing and maintenance of the worker in an occupational environment adapted to his physiological and psychological capabilities; and, to summarize: the adaptation of work to man and of each man to his/her job $[11,12]$.

According to the data of ILO, 270 million occupational accident occur annually in the World, over 313 million workers are involved in non-fatal occupational accidents (it means that everyday over 860.000 workers suffer occupational accident) and 160 million people contract work-related diseases annually [13].

Occupational safety is a scientific and systematic work done so that the employee can be protected from occupational accidents and diseases, benefit from fields such as engineering sciences, law, ergonomics, medical sciences, statistics, economy, mathematic, social politics, behavioral sciences to eliminate or minimize the occupational accidents and diseases in the work places [14].

Occupational Health and Safety is eliminating and minimizing occupational risks caused by working life such as occupational accidents and diseases laying employer, employee and state under legal, medical and technical obligations on the elimination or minimization of the dangers faced by employees against their lives and physical integrities in the working environment [15]. The function of Occupational Health and Safety Services is protecting the workers from the dangers. These can lead to injury, cancer and respiratory, musculoskeletal, fertility, neurologic or dermatologic and mental diseases along with hearing loss in the workplace [16]. According to the classification of Cascio, occupational accidents had two main reasons: (i) unsafe working behaviors, and (ii) unsafe working conditions. Cascio also divides unsafe work conditions into two parts as physical and environmental conditions. Physical conditions include broken equipment, insufficient equipment protector and lack of protective equipment. Noise, radiation, or dust and stress also create unsafe environmental conditions [17].

The first one of the most important steps regarding OHS taken in Turkey, is the Labor Law numbered 4857 and this law gave a different point of view to OHS and with this law it is aimed to bring our country in compliance with the norms of European Union. As a result of it a new concept of 'occupational safety specialist' was added to the literature of OHS. Finally, in order to meet the norms of the European Union, the Law of Occupational Health and Safety numbered 6.331, passed on June 20th, 2012 and published in gazette numbered 28.339, dated on June 30th, 2012 [18].

In Turkey, from 2013 when the OHS law came into force until the end of 2019, last seven years, according to the social security institution data the number of workplaces, the insured worker, the number of insured having work accident by incapacity days, the number of insured with occupational diseases, cases of fatal occupational injury in yea, is shown in Table 1. Looking at Table 1, it is observed that there is an increase of $17 \%$ in the number of workplaces, around $14 \%$ in the number of insured working. A decrease of about $16 \%$ in the number of insured who lost their lives as a result of work accidents and occupational diseases has seen that this ratio is higher when considered with the increase in the number of workplace and employee insured. There is an increase of $120 \%$ in the number of occupational accidents and $209 \%$ in the number of occupational diseases in the 
years specified in Table 1. The reasons for this increase are that the occupational health and safety experts and also the workplace physicians, who are assigned to the companies, guide employers at the point of notifying all occupational accidents, big or small, and that the sanctions and notifications have been increased with the OHS law. Company executives have realized up to date by entering all occupational accidents into the system with the training, information, and guidance provided.

Table 1 Statistical distribution of occupational accidents occurred in Turkey between 2013-2019 [19]

\begin{tabular}{cccccc}
\hline Year & Workplace & $\begin{array}{l}\text { Insured } \\
\text { Worker }\end{array}$ & $\begin{array}{l}\text { Number of } \\
\text { insured having } \\
\text { work accident } \\
\text { by incapacity } \\
\text { days }\end{array}$ & $\begin{array}{l}\text { Number of } \\
\text { insured } \\
\text { having } \\
\text { occupational } \\
\text { disease }\end{array}$ & $\begin{array}{l}\text { Cases of } \\
\text { fatal } \\
\text { occupational } \\
\text { injury in } \\
\text { year }\end{array}$ \\
\hline 2013 & 1.611 .292 & 12.484 .113 & 191.389 & 351 & 1.360 \\
2014 & 1.679 .990 & 13.240 .122 & 221.366 & 494 & 1.626 \\
2015 & 1.740 .187 & 13.999 .398 & 241.547 & 510 & 1.252 \\
2016 & 1.749 .240 & 13.415 .843 & 286.068 & 597 & 1.405 \\
2017 & 1.874 .682 & 14.477 .817 & 359.653 & 691 & 1.633 \\
2018 & 1.879 .771 & 14.229 .170 & 430.985 & 1044 & 1.541 \\
2019 & 1.891 .512 & 14.314 .313 & 422.463 & 1088 & 1.147 \\
\hline
\end{tabular}

The number of workplaces and insured employee in leather industry are shown in Table 2. As it is seen from this table, the majority of the workplaces where leather-related products are small and medium sized enterprises. There are 65.257 registered employees in a total of 6.544 workplaces. Most of the workplaces are enterprises with less than 10 employees. The number of enterprises with more than 250 employees is only 7 .

Table 2 The size of the workplaces in leather industry [19]

\begin{tabular}{|c|c|c|c|c|c|}
\hline \multirow{3}{*}{$\begin{array}{l}\text { Activity Groups } \\
\text { according to the } \\
\text { classification }\end{array}$} & \multirow{2}{*}{\multicolumn{4}{|c|}{$\begin{array}{c}\text { Number of workplaces } \\
\text { Number of insured workers in the } \\
\text { workplace }\end{array}$}} & \multirow[t]{3}{*}{ Total } \\
\hline & & & & & \\
\hline & $1-9$ & $10-49$ & $50-250$ & $250-1000+$ & \\
\hline $\begin{array}{l}\text { Manufacturing of } \\
\text { leather-related } \\
\text { products }\end{array}$ & 5.222 & 1.121 & 194 & 7 & 6.544 workplaces \\
\hline
\end{tabular}

Number of deaths caused by occupational accidents and diseases in leather and all other industries of the year 2019 are shown in Table 3.1.147 workers died from the occupational accidents in overall industries and majority of these workers were male. 1039 occupational accidents, 4 occupational disease and 2 fatal occupational accident occurred in the workplaces where leather-related products are manufactured.

Table 3 Number of deaths caused by occupational accidents and diseases [19]

\begin{tabular}{l|ccc}
\hline \multirow{2}{*}{ Economic Activity Classification } & \multicolumn{3}{|c}{$\begin{array}{c}\text { Number of insured people died due } \\
\text { occupational accident and diseases }\end{array}$} \\
\cline { 2 - 4 } & Male & Female & Total \\
\hline $\begin{array}{l}\text { Manufacturing of leather-related } \\
\text { products } \\
\text { Overall industries total }\end{array}$ & 1 & 1 & 2 \\
\hline
\end{tabular}




\section{Risk Assessment Methods}

In general; 'risk concept' can be defined as "combination of the possibility of occurrence of a specific hazardous incident and the damage, loss or injury caused by the results of this incident. Actually, it should be focused on the assessment and management of risk instead of defining the risk concept $[20,21]$.

The risks put the labor force, equipment, competitiveness and economy in jeopardy [22]. The risk is higher at small businesses. Additionally, their ability of risk inspection is lower. Small businesses may be more advantageous in terms of psychosocial risks [23, 24]. All potential work-related risks need to be identified and assessed in advance. In many countries, this process is laid down in OSH legislation [25].

The health and safety management system is not effective unless accompanied by a positive safety culture in the workplace. The International Labor Organization (ILO) noted that a key element for occupational safety and health management is promoting a culture of prevention within the enterprise. Introduction of a positive safety culture can therefore achieve further reductions in occupational injuries and diseases [26].

Risk analysis methods are divided into two groups; these are quantitative and qualitative methods. Quantitative risk analysis uses numerical methods when it calculates the risk. In qualitative risk analysis, numeric values are given to the values such as the probability of threat occurrence and the effect of the threat; and the risk value is found by processing these values with mathematical and logical methods [27]. The main risk analysis methods can be given as Primary Risk Analysis performed by using Checklist, Risk Assessment based on Decision Matrix Methodology (L-type and X-type Matrix), Hazard and Operability Analysis (HAZOP), Failure Mode and Effects Analysis (FMEA), Fault Tree Analysis-FTA, Cause-Effect Analysis and Fine-Kinney Method [28].

Fine-Kinney Method: With this method, the results of potential risks are ranked. In the event that the threat occurred, the size of the damage or loss to be occurred on human, workplace and environment are evaluated. It is widely used, and its usage is simple. This method makes it possible to use the workplace statistics. It is determined which precautions will be taken in the first place, according to the size of the risk value and it is prioritized according to the risk level [29]. What matters most is, that the values of probability, frequency and severity should be defined in a proper manner. Multiplying the values of probability, frequency and severity will give us the risk value (Risk = Probability $\mathrm{x}$ Frequency $\mathrm{x}$ Severity) [30]. In the formula, probability is the possibility of damage or accident occurring over time, frequency refers to the frequency of exposure to hazard. Severity represents the magnitude of the harm or damage to human, workplace and environment if the hazard occurs. When scoring the severity, one person's death is set as 40 points and more than one death is set as 100 points. The probability, frequency and severity values used in the Fine-Kinney method are shown in Table 4. 
Table 4 Probability (P), Frequency (F) and Severity (S) values used in Fine-Kinney Method [31]

\begin{tabular}{|c|c|c|c|c|c|}
\hline $\begin{array}{l}\text { Probability } \\
\text { Value }\end{array}$ & $\begin{array}{l}\text { Probability } \\
\text { of Damage }\end{array}$ & $\begin{array}{l}\text { Frequency } \\
\text { Value }\end{array}$ & $\begin{array}{l}\text { Frequency of } \\
\text { exposure to } \\
\text { hazard over } \\
\text { time }\end{array}$ & $\begin{array}{l}\text { Severity } \\
\text { Value }\end{array}$ & $\begin{array}{l}\text { Estimated } \\
\text { damage to } \\
\text { human, and } \\
\text { environment }\end{array}$ \\
\hline 10 & $\begin{array}{l}\text { Expected, } \\
\text { certain }\end{array}$ & 10 & $\begin{array}{l}\text { Almost } \\
\text { continuous } \\
\text { Several times } \\
\text { an hour }\end{array}$ & 100 & $\begin{array}{l}\text { More than one } \\
\text { fatal accident } \\
\text { Environmental } \\
\text { disaster }\end{array}$ \\
\hline 6 & $\begin{array}{l}\text { High, } \\
\text { pretty } \\
\text { possible }\end{array}$ & 6 & $\begin{array}{l}\text { Often } \\
\text { Once or several } \\
\text { times a day }\end{array}$ & 40 & $\begin{array}{l}\text { Fatal accident } \\
\text { Serious } \\
\text { environmental } \\
\text { hazard }\end{array}$ \\
\hline 3 & Probable & 3 & $\begin{array}{l}\text { Sometimes } \\
\text { Once or several } \\
\text { times a week }\end{array}$ & 15 & $\begin{array}{l}\text { Permanent } \\
\text { damage/Injury } \\
\text { ' Labor Loss }\end{array}$ \\
\hline 1 & $\begin{array}{l}\text { Possible } \\
\text { but low }\end{array}$ & 2 & $\begin{array}{l}\text { Not often } \\
\text { Once or several } \\
\text { times a month }\end{array}$ & 7 & $\begin{array}{l}\text { Major damage } \\
\text { / injury, } \\
\text { external first } \\
\text { aid }\end{array}$ \\
\hline 0,5 & $\begin{array}{l}\text { Unexpecte } \\
\text { d but } \\
\text { possible }\end{array}$ & 1 & $\begin{array}{l}\text { Rare } \\
\text { Several times a } \\
\text { year }\end{array}$ & 3 & $\begin{array}{l}\text { Minor damage } \\
\text { / injury, } \\
\text { Internal first } \\
\text { aid }\end{array}$ \\
\hline 0,2 & $\begin{array}{l}\text { Unexpecte } \\
\mathrm{d}\end{array}$ & 0,5 & $\begin{array}{l}\text { Very rare } \\
\text { Once or less a } \\
\text { year }\end{array}$ & 1 & $\begin{array}{l}\text { Having a } \\
\text { narrow escape } \\
\text { No } \\
\text { environmental } \\
\text { loss }\end{array}$ \\
\hline
\end{tabular}

Making decisions according to the risk score and assessment of the consequences of the formula and selection the action to be done are shown in Table 5 . 
Table 5 Fine-Kinney method assessment of the consequence, decision and action table [29]

\begin{tabular}{|c|c|c|c|}
\hline \multicolumn{4}{|c|}{ Degree of the results } \\
\hline Value & Explanation & \multicolumn{2}{|c|}{ Category } \\
\hline 1 & $\begin{array}{l}\text { Should be } \\
\text { considered }\end{array}$ & \multicolumn{2}{|c|}{ Light-harmless or insignificant } \\
\hline 3 & Important & \multicolumn{2}{|c|}{ Minor, low labor loss minor loss, first aid } \\
\hline 7 & Serious & \multicolumn{2}{|c|}{$\begin{array}{l}\text { Major, significant harm, external treatment, work-day } \\
\text { loss }\end{array}$} \\
\hline 15 & Very serious & \multicolumn{2}{|c|}{ Disability, loss of limb, environmental impact } \\
\hline 40 & Very bad & \multicolumn{2}{|r|}{ Death, total disability, heavy environmental impact } \\
\hline 100 & Disaster & \multicolumn{2}{|r|}{ More than one death, significant environment disaster } \\
\hline \multicolumn{4}{|c|}{ Decision and Action according to the risk level } \\
\hline Order & Risk Value & Decision & Action \\
\hline 1 & $\mathrm{R}<20$ & $\begin{array}{l}\text { Acceptable } \\
\text { risk }\end{array}$ & Urgent measure may not be needed \\
\hline 2 & $20<\mathrm{R}<70$ & $\begin{array}{l}\text { Absolute } \\
\text { risk }\end{array}$ & Must be included in action plan \\
\hline 3 & $70<\mathrm{R}<200$ & $\begin{array}{l}\text { Significant } \\
\text { risk }\end{array}$ & $\begin{array}{l}\text { Must be monitored carefully and eliminated by } \\
\text { taking it into annual action plan. }\end{array}$ \\
\hline 4 & $200<\mathrm{R}<400$ & High risk & $\begin{array}{l}\text { Must be eliminated by taking it into short-term } \\
\text { action plan. }\end{array}$ \\
\hline 5 & $\mathrm{R}>400$ & $\begin{array}{l}\text { Very high } \\
\text { risk }\end{array}$ & Must take immediate action by breaking off. \\
\hline
\end{tabular}

\section{Research Method and Results}

In this study, cross-sectional research method has been used and the ground floor areas and processes of a leather-processing factory operating in the district of Bolu-Gerede, have been examined [32]. Before the study a risk analysis team has been established consisting of one chief supervisor, two Class-A occupational safety specialists, two Class-B occupational safety specialists, one occupational physician and employer's representative, employee's representative, department head and support members. Risk analysis methods have been examined with team members and for the risk analysis method to be applied in the workplace, Fine-Kinney method has been preferred. Information about Fine-Kinney risk analysis have been conveyed to the team members through training and afterwards field inspections have been done during the whole month and all necessary statistical data have been collected. Near-miss incidents and accident reports of the given business have been examined by team members in detail. Findings obtained, have been evaluated according to the Fine-Kinney risk analysis method and the risk analysis of the company has been generated. After the risk analysis was generated, it has been revised by taking proper steps and repeating the field observations.

\section{Risk Assessment According to Fine-Kinney Method}

Risk scores determined as a result of risk analysis and the risk scores revised after the measures taken against the sources of danger are shown in Table 6, 14 subjects with highest risk scores of the business, are listed. Inadequate personal protective equipment (PPE) to be used by employees against sources of danger, lack of labels for chemicals, lack of handrails on machines and faulty storage in coal storage areas are indicated as very high-risk activities. Specific risk definitions are made for each situation and proper steps are taken urgently for the priority ones. 
Steps taken after risk analysis are shown in Table 6. The risk assessment identified the measures and the regulatory and preventive actions to be taken on the 14 subjects with the highest risk scores. New risk scores calculated after the steps taken are completed, are shown. For instance, personal protective equipment that are inadequate and were not used by employee have been delivered to the employee who must use them, against signature. Employees were informed about the personal protective equipment to be used and their use was controlled by the employer representative.

As a result of risk assessment performed by using Fine-Kinney method, risk score in 10 activities was found as 200 and above. It has been stated that inadequate personal protective equipment, lack of material safety data sheet of chemicals used in production and lack of handrails on machines are the activities with highest score (1200) (Table 6). As a result of the risk assessment, the work was immediately broken off in the areas with high risk scores, and after the risk score was decreased by implementing regulative and preventive activities, the production was restarted. For the unavoidable dangers detected in the workplace, appropriate personal protective equipment has been delivered to the employees as a debit. In consequence of this, risk score decreased to 20. For the chemicals that are in different packages for any reason; chemicals' own labels were put on the packages or containers where the chemicals are placed. Protective shields and handrails which are supposed to be on the machines have been reassembled to their places and the employees were informed through the trainings that they should never remove these preservatives. Risk score decreased to 60 in the relevant subject (Table 6). A problem has been detected in the coal storage activity which is one of the highest-risky matters. It was observed that the preserving and storage of the coals are faulty. In consequence of these faulty situations there is a risk of fire, fall and overturn and the company's managers were informed that they may cause injury and/or death. This situation was identified as "very risky" with 420 risk score (in Table 6), and the coals were stored in accordance with the standards by determining new storage areas for the coals to be used. The risk score decreased to 10.5 after corrective and preventive action.

It has been observed that heavy things are carried by the workers in the business and this was declared by the employees. It was detected that the workers carrying heavy things manually may contract musculoskeletal diseases. Current situation risk assessment team determined the probability value as 3, frequency value as 3 and severity of risk as 40 and risk score has been calculated as 360 . This activity was reported as "high-risk" and it was recommended that it should be taken into the short-term action plan. Employees and employer/employer representative were informed that ancillary lifting equipment must be used to carry heavy loads. These appreciations were taken into consideration by employer representative and risk score was declined to 40 . 
Table 6 Risk assessment form current situation assessment

Risk Assessment Form Current Situation Assessment

Probability (P), Frequency (F), Severity (S), Risk Score (RS)

R $<20$ Acceptable risk, $20<R<70$ Absolute risk, $70<R<200$ Significant risk, $200<R<400$ High- risk, $R>400$ very high risk

\begin{tabular}{|c|c|c|c|c|c|c|c|c|c|c|c|}
\hline \multicolumn{7}{|c|}{ Before Taking Measures } & \multicolumn{5}{|c|}{ After Taking Measures } \\
\hline $\begin{array}{c}\text { Sources of } \\
\text { Danger }\end{array}$ & Result & Current situation & $\mathbf{P}$ & $\mathbf{F}$ & $\mathbf{S}$ & R S & Measures Taken & $\mathbf{P}$ & $\mathbf{F}$ & $\mathbf{S}$ & R S \\
\hline Chemicals & $\begin{array}{l}\text { Occupational } \\
\text { disease, cancer } \\
\text { and/or death. }\end{array}$ & $\begin{array}{l}\text { It has been stated that } \\
\text { personal protective } \\
\text { equipment used for } \\
\text { current and potential } \\
\text { risks in the workplace, } \\
\text { are inadequate. }\end{array}$ & 3 & 10 & 40 & 1200 & $\begin{array}{l}\text { For unavoidable risks detected in } \\
\text { the workplace, appropriate } \\
\text { personal protective equipment } \\
\text { was delivered to employees as a } \\
\text { debit and equipment were used } \\
\text { by employees. }\end{array}$ & 0,5 & 3 & 40 & 60 \\
\hline $\begin{array}{l}\text { No labels of } \\
\text { the chemicals }\end{array}$ & $\begin{array}{l}\text { Occupational } \\
\text { disease, cancer } \\
\text { and/or death. }\end{array}$ & $\begin{array}{l}\text { It has been seen that the } \\
\text { chemicals used in the } \\
\text { workplace are in } \\
\text { different packages. }\end{array}$ & 3 & 10 & 40 & 1200 & $\begin{array}{l}\text { For chemicals in different } \\
\text { packages; chemicals' own labels } \\
\text { were put on the packages or } \\
\text { containers where the chemicals } \\
\text { are placed. }\end{array}$ & 0,5 & 3 & 40 & 60 \\
\hline $\begin{array}{l}\text { No handrails } \\
\text { in the } \\
\text { machines }\end{array}$ & Injury, death & $\begin{array}{l}\text { It has been seen that the } \\
\text { handrails of the } \\
\text { machines were } \\
\text { demounted. }\end{array}$ & 3 & 10 & 40 & 1200 & $\begin{array}{l}\text { Handrails which are supposed to } \\
\text { be on the machines have been } \\
\text { reassembled to their places and } \\
\text { employees were informed that } \\
\text { they should never remove those. }\end{array}$ & 0,5 & 3 & 40 & 60 \\
\hline $\begin{array}{l}\text { Fire, drop } \\
\text { and topple }\end{array}$ & $\begin{array}{l}\text { Injury and/or } \\
\text { death. }\end{array}$ & $\begin{array}{l}\text { It was observed that the } \\
\text { storage of coals to be } \\
\text { used in fueling boiler, } \\
\text { are faulty. }\end{array}$ & 10 & 6 & 7 & 420 & $\begin{array}{l}\text { Coals were stored in accordance } \\
\text { with the standards by building } \\
\text { new storage areas for the coals to } \\
\text { be used. }\end{array}$ & 0,5 & 3 & 7 & 10,5 \\
\hline
\end{tabular}


Table 6 Risk assessment form current situation assessment (cont.)

Risk Assessment Form Current Situation Assessment

Probability (P), Frequency (F), Severity (S), Risk Score (RS)

$\mathrm{R}<20$ Acceptable risk, $20<\mathrm{R}<70$ Absolute risk, $70<\mathrm{R}<200$ Significant risk, $200<\mathrm{R}<400$ High- risk, $\mathrm{R}>400$ very high risk

\begin{tabular}{|c|c|c|c|c|c|c|c|c|c|c|c|}
\hline \multicolumn{7}{|c|}{ Before Taking Measures } & \multicolumn{5}{|c|}{ After Taking Measures } \\
\hline $\begin{array}{c}\text { Sources of } \\
\text { Danger }\end{array}$ & Result & Current situation & $\mathbf{P}$ & $\mathbf{F}$ & $\mathbf{S}$ & R S & Measures Taken & $\mathbf{P}$ & $\mathbf{F}$ & $\mathbf{S}$ & R S \\
\hline Heavy, loads & $\begin{array}{l}\text { Musculoskeletal } \\
\text { diseases }\end{array}$ & $\begin{array}{l}\text { It has been stated that } \\
\text { heavy things are carried } \\
\text { by workers }\end{array}$ & 3 & 3 & 40 & 360 & $\begin{array}{l}\text { Employees and } \\
\text { employer/employer representative } \\
\text { were informed that ancillary lifting } \\
\text { equipment must be used to carry } \\
\text { heavy loads. }\end{array}$ & 1 & 1 & 40 & 40 \\
\hline $\begin{array}{l}\text { Working } \\
\text { environment }\end{array}$ & $\begin{array}{l}\text { Occupational } \\
\text { disease, injury } \\
\text { and/or death. }\end{array}$ & $\begin{array}{l}\text { It was stated that } \\
\text { necessary environment } \\
\text { measurements } \\
\text { (lightening, noise, dust, } \\
\text { thermal comfort etc.) } \\
\text { have not been carried out. }\end{array}$ & 3 & 6 & 15 & 270 & $\begin{array}{l}\text { Necessary env. measurements were } \\
\text { carried out by authorized company. } \\
\text { Eliminating identified warnings } \\
\text { and inadequacies identified in } \\
\text { report, measurements were } \\
\text { repeated. }\end{array}$ & 0,5 & 3 & 15 & 22,5 \\
\hline Noise & $\begin{array}{l}\text { Loss of hear, } \\
\text { headache, lack } \\
\text { of attention }\end{array}$ & $\begin{array}{l}\text { After the environment } \\
\text { measurement, places with } \\
\text { high-decibel sound were } \\
\text { detected. }\end{array}$ & 3 & 6 & 15 & 270 & $\begin{array}{l}\text { In places where sound decibel is } \\
\text { high, employees were given the } \\
\text { earplugs and earmuffs with debit } \\
\text { ticket. }\end{array}$ & 1 & 2 & 15 & 30 \\
\hline $\begin{array}{l}\text { Lack of } \\
\text { technical } \\
\text { training }\end{array}$ & $\begin{array}{l}\text { Occupational } \\
\text { disease, injury } \\
\text { and/or death. }\end{array}$ & $\begin{array}{l}\text { It was stated that the } \\
\text { occup. training and cert. } \\
\text { of competency of } \\
\text { employees were } \\
\text { insufficient. }\end{array}$ & 3 & 6 & 15 & 270 & $\begin{array}{l}\text { Occupational trainings of the } \\
\text { employees whose trainings were } \\
\text { inadequate were completed and } \\
\text { they became certificated } \\
\text { employees. }\end{array}$ & 0,5 & 2 & 15 & 15 \\
\hline
\end{tabular}


Table 6 Risk assessment form current situation assessment (cont.)

Risk Assessment Form Current Situation Assessment

Probability (P), Frequency (F), Severity (S), Risk Score (RS)

$\mathrm{R}<20$ Acceptable risk, $20<\mathrm{R}<70$ Absolute risk, $70<\mathrm{R}<200$ Significant risk, $200<\mathrm{R}<400$ High- risk, $\mathrm{R}>400$ very high risk

\begin{tabular}{|c|c|c|c|c|c|c|c|c|c|c|c|}
\hline \multicolumn{7}{|c|}{ Before Taking Measures } & \multicolumn{5}{|c|}{ After Taking Measures } \\
\hline $\begin{array}{l}\text { Sources of } \\
\text { Danger }\end{array}$ & Result & Current situation & $\mathbf{P}$ & $\mathbf{F}$ & $\mathbf{S}$ & R S & Measures Taken & $\mathbf{P}$ & $\mathbf{F}$ & $\mathbf{S}$ & R S \\
\hline $\begin{array}{l}\text { Emergency } \\
\text { exit }\end{array}$ & $\begin{array}{l}\text { Injury and/or } \\
\text { death. }\end{array}$ & $\begin{array}{l}\text { It was observed that there } \\
\text { were obstructive } \\
\text { materials in the front and } \\
\text { back parts of the doors. }\end{array}$ & 6 & 1 & 40 & 240 & $\begin{array}{l}\text { These obstructive materials } \\
\text { blocking the emergency exits were } \\
\text { removed and they were inspected. }\end{array}$ & 0,5 & 0,5 & 40 & 10 \\
\hline $\begin{array}{l}\text { Emergency } \\
\text { Health and } \\
\text { safety signs }\end{array}$ & $\begin{array}{l}\text { Injury and/or } \\
\text { death. }\end{array}$ & $\begin{array}{l}\text { It was seen that guide } \\
\text { signs are inadequate and } \\
\text { out of standards in } \\
\text { emergency. }\end{array}$ & 1 & 2 & 100 & 200 & $\begin{array}{l}\text { Emergency guide signs were placed } \\
\text { on necessary areas in accordance } \\
\text { with standards. }\end{array}$ & 0,5 & 0,5 & 100 & 25 \\
\hline First aid staff & $\begin{array}{l}\text { Injury and/or } \\
\text { death. }\end{array}$ & $\begin{array}{l}\text { It was observed that there } \\
\text { are insufficient numbers } \\
\text { of first aiders in } \\
\text { workplace. }\end{array}$ & 6 & 2 & 15 & 180 & $\begin{array}{l}\text { Employees identified as 'first-aider' } \\
\text { were certificated and they received } \\
\text { training from the occup. physician. }\end{array}$ & 1 & 0,5 & 15 & 7,5 \\
\hline $\begin{array}{l}\text { Health and } \\
\text { safety signs }\end{array}$ & $\begin{array}{l}\text { Injury and/or } \\
\text { death. }\end{array}$ & $\begin{array}{l}\text { It has been seen that } \\
\text { health and safety signs } \\
\text { are inadequate in the } \\
\text { workplace. }\end{array}$ & 3 & 3 & 15 & 135 & $\begin{array}{l}\text { Inadequate health and safety signs } \\
\text { were placed. }\end{array}$ & 0,5 & 2 & 15 & 15 \\
\hline Motor vehicles & $\begin{array}{l}\text { Traffic } \\
\text { accident; } \\
\text { injury and/or } \\
\text { death. }\end{array}$ & $\begin{array}{l}\text { It was stated that the } \\
\text { drivers of motor vehicles } \\
\text { used inside the workplace } \\
\text { have driving license, but } \\
\text { some employees also use } \\
\text { them without license. }\end{array}$ & 3 & 3 & 15 & 135 & $\begin{array}{l}\text { The employees were informed that } \\
\text { the employees should not drive the } \\
\text { vehicles without license. }\end{array}$ & 0,5 & 2 & 15 & 15 \\
\hline
\end{tabular}


Table 6 Risk assessment form current situation assessment (cont.)

Risk Assessment Form Current Situation Assessment

Probability (P), Frequency (F), Severity (S), Risk Score (RS)

$\mathrm{R}<20$ Acceptable risk, $20<\mathrm{R}<70$ Absolute risk, $70<\mathrm{R}<200$ Significant risk, $200<\mathrm{R}<400$ High- risk, $\mathrm{R}>400$ very high risk

\begin{tabular}{|c|c|c|c|c|c|c|c|c|c|c|c|}
\hline \multicolumn{7}{|c|}{ Before Taking Measures } & \multicolumn{5}{|c|}{ After Taking Measures } \\
\hline $\begin{array}{c}\text { Sources of } \\
\text { Danger }\end{array}$ & Result & Current situation & $\mathbf{P}$ & $\mathbf{F}$ & $\mathbf{S}$ & R S & Measures Taken & $\mathbf{P}$ & $\mathbf{F}$ & $\mathbf{S}$ & R S \\
\hline $\begin{array}{l}\text { Long-term } \\
\text { standing work }\end{array}$ & $\begin{array}{l}\text { Occupational } \\
\text { disease }\end{array}$ & $\begin{array}{l}\text { A specific rest-break time } \\
\text { has not been identified for } \\
\text { workers standing for long } \\
\text { periods. }\end{array}$ & 3 & 3 & 15 & 135 & $\begin{array}{l}\text { Specific rest-break time has been } \\
\text { identified for workers standing for } \\
\text { long periods and these time periods } \\
\text { have been implemented. }\end{array}$ & 0,5 & 1 & 15 & 7,5 \\
\hline
\end{tabular}


As a result of the risk assessment, the work was immediately broken off in the areas with high risk scores, and after the risk score was decreased by implementing regulative and preventive activities, the production was restarted. For the use of chemicals dangerous detected in the workplace, appropriate personal protective equipment has been delivered to the employees as a debit. In consequence of this, risk score decreased to 60. For the chemicals that are in different packages for any reason; chemicals' own labels were put on the packages or containers where the chemicals are placed. Protective shields and handrails which are supposed to be on the machines have been reassembled to their places and the employees were informed through the trainings that they should never remove these preservatives. Risk score decreased to 60 in the relevant subject (Table 6). A problem has been detected in the coal storage activity which is one of the highest-risky matters. It was observed that the preserving and storage of the coals are faulty. In consequence of these faulty situations there is a risk of fire, fall and overturn and the company's managers were informed that they may cause injury and/or death. This situation was identified as "very risky" with 420 risk score (in Table 6), and the coals were stored in accordance with the standards by determining new storage areas for the coals to be used. The risk score decreased to 10.5 after corrective and preventive action.

It has been observed that heavy things are carried by the workers in the business and this was declared by the employees. It was detected that the workers carrying heavy things manually may contract musculoskeletal diseases. Current situation risk assessment team determined the probability value as 3, frequency value as 3 and severity of risk as 40 and risk score has been calculated as 360 . This activity was reported as "high-risk" and it was recommended that it should be taken into the short-term action plan. Employees and employer/employer representative were informed that ancillary lifting equipment must be used to carry heavy loads. These appreciations were taken into consideration by employer representative and risk score was declined to 40 .

It was detected that the following are high-risk issues and the risk score were determined as 270 for these issues: The environment measurement has not been carried out, that the sound level was high, and the occupational training of the employees were insufficient. Business executives were informed that it should be taken into the short-term action plan. Necessary environment measurements have been carried out by authorized company. The warnings and inadequacies identified in the report were removed and the measurements were repeated. In the places where sound decibel is high, employees were given the earplugs and earmuffs with debit ticket. Occupational trainings of the employees whose trainings were inadequate were completed. Risk score of these activities have been decreased after the efforts made.

Emergency exits were specified as "source of danger" and were given 240 points as risk score. It was observed that there were obstructive materials in the front and back parts of the doors. This situation was specified as high-risky and the employer representative was warned about it and these obstructive materials blocking the emergency exits were removed and the employees were informed about the importance of this issue. At the end of the observations made after warning and informing, it was seen that the employees and managers abided by these. The fact that guide signs are inadequate and out of standards, was another high-risk factor. The risk score, which was determined as 200 , decreased to 25 after the emergency guidance boards and signs became in accordance with standards.

In the risk analysis performed in the business, less risk scores have been determined in other activities. It has been reported to the company executives that high-risk issues should being monitored carefully and that these risks should be eliminated by taking them into annual action plan. The activities identified as 'absolute risk' were included in the action plan. It is stated that no immediate action is required for reasonable risks, but it is 
essential to take measures. As a result, the issues with high and very high-risk scores were eliminated urgently and the safety of the workplace and employees was ensured considerably.

\section{Conclusion and Recommendations}

In the companies operating in the field of leather industry, there are significant hazards and the risks caused by these hazards. The possibility of occurrence of occupational accidents is high due to the machinery and the large number of chemicals, therefore it is quite important to carry out the risk analysis in the workplace.

In this study, using Fine-Kinney method, the risk analysis was carried out and the risk scores of the potential risks were identified. As a result of the risk analysis, the issues with high and very high-risk scores were evaluated urgently and the necessary regulative and preventive operations have been carried out. By this way, the risk scores have been lowered and the safety of the employees and the workplace is maintained. As it is seen in the case study, it is very important to carry out risk analysis and to take measures according to the results. For this reason, it was understood that it is very important to take measures for the high-risk scores identified by the risk analysis and that the action plan should be completed immediately and put into operation by breaking off if necessary.

By performing the risk analysis, a proactive approach to occupational health and safety practices has been exhibited, the occurrence of future occupational accidents is prevented and the damage to be given to workers, employers and the economy is avoided. It is utmost important to perform the risk analysis carefully throughout the country and in all sectors in terms of health and safety at work.

\section{References}

1. Thomson R and Kite M. Conservation of leather and related materials. Oxford: Butterworth-Heinemann; 2006.

2. Kudryavtsev SS, Yemelin PV and Yemelina NK. The development of a risk management system in the field of industrial safety in the Republic of Kazakhstan, Safety and Health at Work, 2018;9(1):30-41.

3. Bufalo G, Di Nezza F, Cimmino L, Cuomo F and Ambrosone L. Physicochemical investigation of ultrasound effects on some steps of mink fur processing. A suggestion for improving the worker health and reducing the environmental impact, Journal of Cleaner Production, 2017;143(1):10-16.

4. Issever H, Ozdilli K, Ayhan Ozyildirim B, Hapcioglu B, Ince N, Ince H, Isik E, Akcay E, Yegenoglu Y, Erelel M, Calak B and Agbas N. Respiratory problems in tannery workers in Istanbul, Indoor Built Environ, 2007;16:177-83.

5. Kornhauser C, Wrobel K, Wrobel K, Malacara JM, Nava LE, Gomez L and Gonzalez R. Possible adverse effect of chromium in occupational exposure of tannery workers, Industrial Health, 2002;40:207-213.

6. Were FH, Moturi MC, Gottesfeld P, Wafula GA and Kamau GN. Lead exposure and blood pressure among workers in diverse industrial plants in Kenya, Journal of Occupational And Environmental Hygiene, 2014;11(11):706-715.

7. Gul M, Mete S, Serin F and Celik E. Fine-Kinney occupational risk assessment method and its extensions by Fuzzy sets: A state-of-the-art review. In: FineKinney-Based Fuzzy Multi-Criteria Occupational Risk Assessment. Switzerland: Springer Nature; 2021. p. 91-110. 
8. Can GF and Toktas P. An advanced stochastic risk assessment approach proposal based on KEMIRA-M, QFD and Fine-Kinney hybridization, International Journal of Information Technology \& Decision Making, 2021;20(1):431-468.

9. Isler MC. International sources and occupational health and safety law no. 6331. CSGB Journal of Labor World, 2014;2(2):53-65.

10. Demircioglu AM and Tankut C. Labor law. Istanbul: Beta Publication; 2003.

11. Alli BO. Fundamental principles of occupational health and safety. Geneva: ILO Publication; 2001.

12. Baloglu C. Liabilities occupational health and safety enforcement in the event of discrepancy, Public-Work, 2013;13(2): 99-125.

13. Occupational Health and Safety, TMMBO, Ankara, 2018.

14. Dizdar EN. Occupational safety. Trabzon: Murathan Publisher; 2008.

15. Tiftik $M$ and Adiguzel, A. Employer's protection liability according to the law of occupational health and safety, Yıldırım Beyazıt Law Journal, 2016;1:319-356.

16. Harrison J and Dawson L. Occupational health: Meeting the challenges of the next 20 years, Saf Health Work, 2016;7:143-149.

17. Cascio WF. Managing human resources. New York: Mcgraw-Hill College; 1995.

18. Songur L, Songur G. Situation analysis of the very hazardous businesses operating in KOP region. Journal of Kastamonu University Economics and Administrative Sciences Faculty, 2018;20(4):219-235.

19. Annual of Statistics 2007-2017, Republic of Turkey Social Security Institution, Ankara, 2017.

20. Zhang-Lin G, Jing T and Hui-Qiang S. On the understanding of risk concept. In: 1st International Advances in Studies on Risk Analysis and Crisis Response, Shanghai, China. 2007. p. 329-333.

21. Van den Honert AF and Vlok PJ. Estimating the continuous risk of accidents occurring in the mining industry in South Africa, South African Journal of Industrial Engineering. 2015;26(3):71-85.

22. Mohammadfam I, Kamalinia M, Momeni M, Golmohammadi R, Hamidi Y and Soltanian A. Evaluation of the quality of occupational health and safety management systems based on key performance indicators in certified organizations, Safety and Health at Work, 2017;8:156-161.

23. Leka $S$ and Jain A. Health impact of psychosocial hazards at work: An overview. Geneva: World Health Organization; 2010.

24. Hasle P and Limborg HJ. A review of the literature on preventive occupational health and safety activities in small enterprises, Industrial Health, 2006;44:6-12.

25. Sun Y, Arning M, Bochmann F, Börger J and Heitmann T. Development and validation of a practical instrument for injury prevention: The occupational safety and health monitoring and assessment tool (OSH-MAT), Safety and Health at Work, 2018;9:140-143.

26. Kim Y, Park J and Park M. Creating a culture of prevention in occupational safety and health practice, Safety and Health at Work, 2016;7:89-96.

27. Ozkilic 0. Occupational health and safety management systems and risk assessment methodologies. Istanbul: TISK Publication; 2005.

28. Oturakci M and Dagsuyu C. Fine-Kinney method in risk assessment, Occupational Health and Safety Journal of Karaelmas, 2017;1(1):17-25.

29. Seber V. How to do risk assessments in occupational health and safety, Journal of Electrical Engineering, 2012;445:30-34.

30. Tasci MO. Risk assessment application at a bag manufacturer firm in terms of occupational health and safety, Master's Thesis, Istanbul Yeni Yüzyll University, Istanbul, Turkey 2018. 
31. Kinney GF and Wiruth AD. Practical risk analysis for safety management, China Lake CA: NWC Technical Publication 5865; 1976.

32. Karasar N. Scientific research methods. Ankara: Nobel Publishing House; 2008. 